\title{
REALITAS SOSIAL DALAM SENI POSTER SEBUAH KAJIAN KARYA POSTER SHEPARD FAIRY
}

\author{
Dwi Haryanto \\ Mahasiswa Pascasarjana ISI Yogyakarta, \\ Dosen Jurusan Disain Komunikasi Visual \\ Akademi Seni Rupa dan Disain "MSD" Yogyakarta \\ Email: mr_d210@yahoo.co.id
}

\begin{abstract}
A poster, briefly dominated the visual element that is able to seize the attention of the audience rather than the verbal element. However, in fact that would be submitted by a poster is "information" or a particular message. Obey Giant poster artwork which is the object of this study represent a designer, Shepard Frairy, in expressing ideas and imagination as part of the social environment in its own way. Though the visual imagination unusual phenomenon would lead to different design styles. Posters can be a medium of expression as a person over the sociological phenomenon.

In describing a sociological study will be a lot of talk varied possibilities in understanding a work of design, so that design work should be understood as a being who does not stand alone and require more extensive exposure of the public support. Obey Giant poster-style works Shepar Fairy, in a sociological context does not appear out of nowhere and grows by itself into a large art construction. In the process, the work produced naturally through a social process.

The process of creation of the work of Shepard Fairy gradually much influenced by several factors that are subjective (emotional factors, the nature, the power of images, and mental processes) as well as objective factors that include factors of social institutions, society, geography, religion, and various other factors, so that the whole can be understood as a part of the components that build artistic construction of the designer.
\end{abstract}

Keywords: Poster, Sociology, Social process

\section{Pendahuluan}

Beberapa waktu yang lalu, di seputaran wilayah Yogyakarta ada hal menarik, dimana hampir di setiap ruang terbuka publik terpasang selebaran dengan berbagai ukuran yang memuat gambar aktifis HAM Munir dengan disertai Tulisan "Kami Tetap Ada dan Berlipat Ganda". Pada saat yang sama di beberapa tempat di seputaran Yogyakarta juga ditemukan poster stensilan wajah Munir dengan disertai tulisan "menolak lupa".

Serangkaian gambar Munir dalam bentuk poster dan ilustrasi dinding tersebut sesaat menimbulkan beragam interpretasi dan pertanyaan. Berbagai pertanyaan ada apa, mengapa dan bagaimana muncul dalam benak penulis. Poster ditempel berurutan seolah saling berebutan dengan poster-poster lain yang tertempel di dinding bangunan pinggir jalan, bahkan ada diantaranya yang ditempel di atas dinding yang agak tinggi yang berangkali agar "tidak mudah tangan" (dilepas) atau barangkali agar dapat lebih terlihat.

Gaya ilustrasi dengan pewarnaan hitam putih dan penggunaan teks sederhana mengingatkan pada sebuah gerakan visual yang dipelopori oleh Shepard Fairy, seorang desainer grafis dari Rhode Island School of Design. Ia menjadi sosok di balik lahirnya fenomena seni postmodern dengan gagasannya tentang propagandart Obey Giant. Gerakan seni visual jalanan yang digagasnya begitu kuat pengaruhnya bagi seniman lain untuk mengadopsi gaya visual tersebut yang seolah dianggap memiliki kesamaan semangat ideologi dan perjuangan dalam gerakangerakan sosial untuk menyuarakan kepentingan arus bawah. Gerakan yang diawali oleh Shepard Fairy ini menjadi sebuah fenomena baru dalam dunia seni visual desain. Berangakat dari 


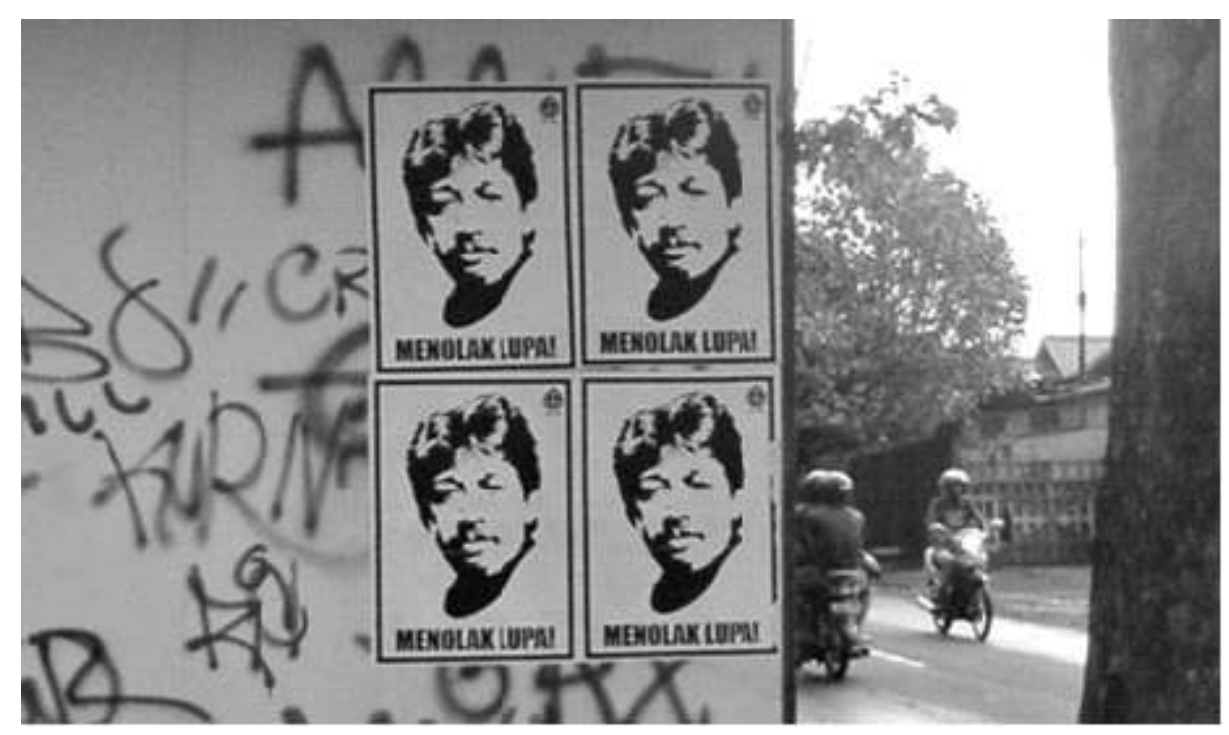

Gambar 1. Poster Menolak lupa kasus Munir Sumber: http://antitankproject.files.wordpress.com/2008/09/weekend-work4.jpg

fenomena-fenomena ini membuktikan bahwa dalam kondisi tertentu, seni atau dalam konteks tulisan ini berkaitan dengan fenomena desain berhubungan dengan isu kekuasaan, berhubungan juga dengan persoalan kelas sosial, dengan norma yang bersifat lokal, dan juga berhubungan dengan permasalahan politik.

Poster-poster yang dibuat menjadi salah satu media yang digunakan Shepard Frairy dalam mengungkapkan gagasan dan imajinasinya sebagai bagian dari makhluk sosial. Imajinasiimanjinasi tersebut diwujudkan dalam bentuk ekspresi gaya visual poster. Dalam pengertian lain ekspresi dapat berarti kemampuan intuitif yang diperoleh melalui pengkhayalan tentang hal-hal individual yang menghasilkan gambarangambaran angan-angan. Dengan demikian pengungkapan berwujud berbagai gambaran angan-angan seperti misalnya images warna, garis dan kata. Bagi seseorang mengungkapkan berarti menciptakan seni dalam dirinya tanpa perlu adanya kegiatan jasmaniah keluar. Pengalaman estetis seseorang tidak lain adalah ekspresi dalam gambar dan angan-angan (The Liang Gie 1976: 75). Segala sesuatu adalah ideal yang merupakan aktivitas pikiran. Aktivitas pikiran dibagi menjadi dua yaitu yang teoritis (logika dan estetika), dan yang praktis (ekonomi dan etika).

Kreatifitas dalam menampilkan persoalan sosial yang diperlihatkan Sheppard Fairy dalam setiap posternya dapat ditangkap sebagai bentuk pengalaman sosial yang berusaha digulirkan kembali ke masyarakat agar menjadi perhatian publik. Proses kreatif sebagai proses mental dimana pengalaman masa lampau dikombinasikan kembali, sering dalam bentuk yang diubah sedemikian rupa sehingga timbul pola-pola baru, bentuk-bentuk baru yang lebih baik untuk mengatasi kebutuhan tertentu (Arnolt dalam Bastomi, 1990: 108).

Poster merupakan salah satu wujud dari budaya visual dalam kehidupan manusia. Poster sesungguhnya bentuk tertua, dalam beberapa hal, yang "termurni" dari periklanan karena sebuah poster merepresentasikan sesuatu yang hendak dijual dengan menempelkannya di tembok (Meyers, 1999: 96). Dalam arti bahwa apa yang dijual dapat berupa beragam produk konsumtif, gaya hidup, kebijakan penguasa (pemerintah), maupun ideologi. 
Dalam sebuah poster, secara selintas unsur visual (piktorial) lebih mampu merebut perhatian khalayak daripada unsur poster beupa teks verbal. Meskipun elemen visual menjadi lebih dominan, namun sesungguhnya yang hendak disampaikan oleh sebuah poster adalah "informasi" atau pesan tertentu. Integrasi antara yang tekstual dan visual tidaklah sekadar kaitan sederhana, melainkan saling bersenyawa. Jadi dalam dalam mengamati sebuah poster kita harus melihat secara keseluruhan, tidak secara parsial dalam memaknai maksud dari muatan isi poster. Sebuah poster tidak akan membiarkan manakala dihilangkan satu elemen darinya tanpa merusak desainnya.

\section{Pendekatan Teoritik}

Dalam mengkaji poster gaya Shepard Fairy seperti pada topik tulisan ini, diperlukan kerangka teoritis yang relevan dengan masalah yang di telaah. Teori yang di bangun tentunya bukan hanya sebagai penunjuk daya serap atau bahkan hanya berfungsi sebagai kutipan saja. Teori akan tetap penting sebagai kerangka teoritis sehingga di dalamnya akan mencakup penggolongan, pemaknaan dan inferensi. Teori menjadi alat dan cara membedah permasalahan ilmiah yang akan dikaji dan dijabarkan.

Dalam memaparkan suatu kajian yang bersifat sosiologis akan banyak berbicara berbagai kemungkinan dalam memahami suatu karya seni, sehingga karya seni di telaah sebagai suatu wujud yang tidak berdiri sendiri dan memerlukan paparan yang lebih luas mengenai masyarakat sosial pendukungnya. Untuk membahas permasalahan seni poster gaya Obey Giant karya Shepard Fairy memerlukan suatu kerangka secara teoritis guna mendapatkan paparan yang mampu mengungkapkan permasalahan secara kritis dari sudut pandang sosiologisnya.
Seni poster gaya Obey Giant karya Shepar Fairy secara sosiologis tidak muncul begitu saja dan serta merta berdiri sendiri menjadi suatu konstruksi seni yang besar. Dalam perjalanan berkarya seninya tentunya melalui sebuah proses sosial dan persoalan seni pada hakekatnya dapat dipahami memiliki suatu tujuan tersendiri. Proses penciptaan karya Shepard Fairy secara bertahap banyak di pengaruhi oleh beberapa faktor yang bersifat subjektif maupun faktor-faktor objektifnya. Faktor subjektif yang mempengaruhi antara lain faktor individu baik emosi, sifat, dan imajinasi serta seluruh proses kejiwaan seniman dalam menerima dan mengolah berbagai hal yang ada disekitarnya. Faktor objektif disini meliputi faktor institusi sosial, masyarakat, faktor geografis, agama, dan berbagai faktor lainnya, sehingga secara keseluruhan dapat dipahami sebagai suatu bagian komponen-komponen yang membangun konstruksi seni sang seniman.

Melalui telaah pandangan yang dikemukakan tersebut menurut Vera L. Zolberg, dalam bukunya Constructing a Sociology of the Art diungkapkan bahwa; objek seni sebagai proses sosial, melalui pengertian ini karya seni dipahami atas dasar proses penciptaannya sehingga suatu karya yang didefinisikan sebagai seni, selanjutnya seni sendiri menjadi sebuah objek yang harus di rekonstruksi untuk menunjukkan aspek struktur sosial dan proses menggunakan sumber-sumber indikator apapun yag tersedia (Zolberg, 1990: 79$80)$.

Pada pandangan ini suatu karya seni dianggap sebagai produk usaha bersama antara komponen-komponen yang membentuk seniman dan karyanya. Pandangan tersebut juga memiliki hubungan dengan pendekatan Howard S. Becker, dalam bukunya Art Worlds, bahwa seni sebagai konstruksi sosial yang dipahami secara baik 
dengan melibatkan beberapa aktor termasuk beberapa yang kekuasaan sosialnya memungkinkan mereka untuk menekankan nilai pada objek (Zolberg, 1990: 80).

Pandangan Zolberg yang digunakan sebagai pijakan analisis adalah pendapatnya yang mengungkapkan bahwa; para sarjana menemukan secara alami konstruksi sosial seni yaitu; seniman, masyarakat, dan institusi budaya. Teori inilah yang dipakai sebagai pendekatan utamanya, disamping itu juga digunakan pendekatan Becker, selanjutnya di aplikasikan untuk menelaah kajian seperti; senimannya, lembaga pendidikan, galeri, kelompok sosial masyarakat dan lain sebagainya.

\section{Pembahasan}

\section{Shepard Fairy dan Karyanya}

Shepard Fairy lahir dan dibesarkan di Charlestone, South Carolina. Ia lahir dari keluarga kelas menengah dari ayah Strait Fairy yang seorang dokter dan ibunya Charlotte. Shepard mengawali aktifitas seni pada tahun 1984 ketika ia mulai membuat karya drawing pada papan Skateboard dan T-Shirt yang merupakan hobi kebanyakan yang dilakukan anak-anak di lingkungan tempat tinggalnya.

Pendidikan formal diperoleh setelah lulus dari Idyllwild Arts Academy pada tahun 1988, dan pada tahun 1992 Shepard Fairy lulus dari Rhode Island School of Design dengan gelar Bachelor of Fine Art pada bidang keahlian ilustrasi. Selama kuliah disana ia bekerja paruh waktu pada toko skateboard bernama Providence yang berada di wilayah dekat kampusnya.

Gerakan yang diawali oleh Shepard Fairy ini menjadi sebuah fenomena baru dalam dunia desain. Dan yang menarik bahwa gerakan ini dilakukan secara kebetulan. Berbagai kontroversi muncul atas fenomena seni avant garde atau beberapa menyebutnya sebagai seni 'kekonyolan'. Bagi penganut Marxisme barangkali fenomena ini adalah sesuatu yang tidak sejalan dengan paham mereka, mengingat segala sesuatu yang dihasilkan dari gerakan ini sama sekali tidak membawa pesan (setidaknya secara implisit) apalagi yang mengarah ke seni bertendensi (untuk pembebasan kelas). Tetapi terlepas dari itu setiap hasil karya dari gerakan ini seperti mempunyai kekuatan untuk mempengaruhi, menarik perhatian, bahkan menghipnotis untuk melakukan atau memikirkan

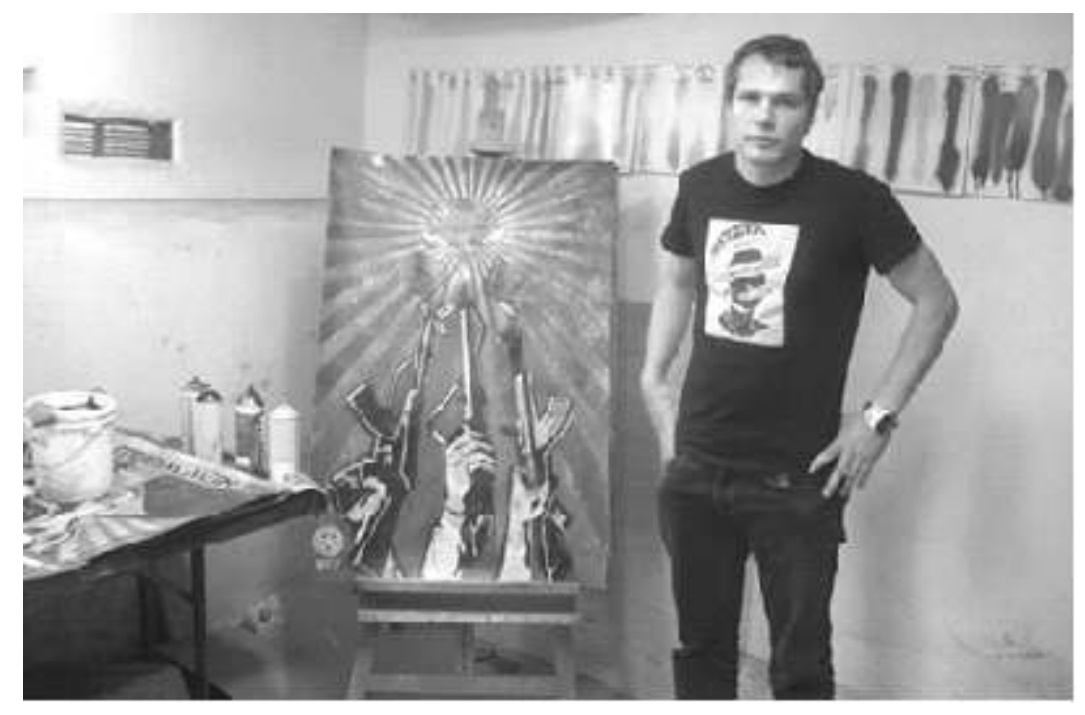

Gambar 2. Shepard Fairy

Sumber: http://www.theblaze.com/stories/2012/02/24/ 
sesuatu yang kita tidak benar-benar pasti apa itu.

Seolah-olah setiap gambar yang terpampang adalah hal yang sangat penting, sehingga mengharuskan kita untuk paling tidak melihatnya selama beberapa saat. Meskipun pada awalnya gaya visualisasi yang ditampilkan oleh Shepard tidak dalam rangka membawa gagasan tertentu, namun dalam perjalananya ternyata membawa pengaruh dan seolah menjadi model media propaganda terutama dalam kampanye gerakan sosial dalam menentang segala bentuk ketidakadilan dan hegemoni kekuasaan politik, sosial, ekonomi maupun kebudayaan. Dalam hal
Andre diyakini Shepard mempunyai kekuatan sebagai obyek yang sempurna dan tak ada matinya untuk dipakai sebagai dasar karya grafis. Dari situ ia dan seorang temannya membuat stensilan dan stiker dengan gambar 'Andre the Giant has a posse', yang ditempel di berbagai tempat strategis dan menarik perhatian. Di luar dugaan, ternyata setiap orang yang melihatnya dibuat penasaran dan bertanya-tanya tentang apa sebenarnya semua gambar tersebut. Banyak stiker-stiker yang hilang dari tempat asalnya ditempel dan berpindah ke topi, mobil, dan papan skateboard.

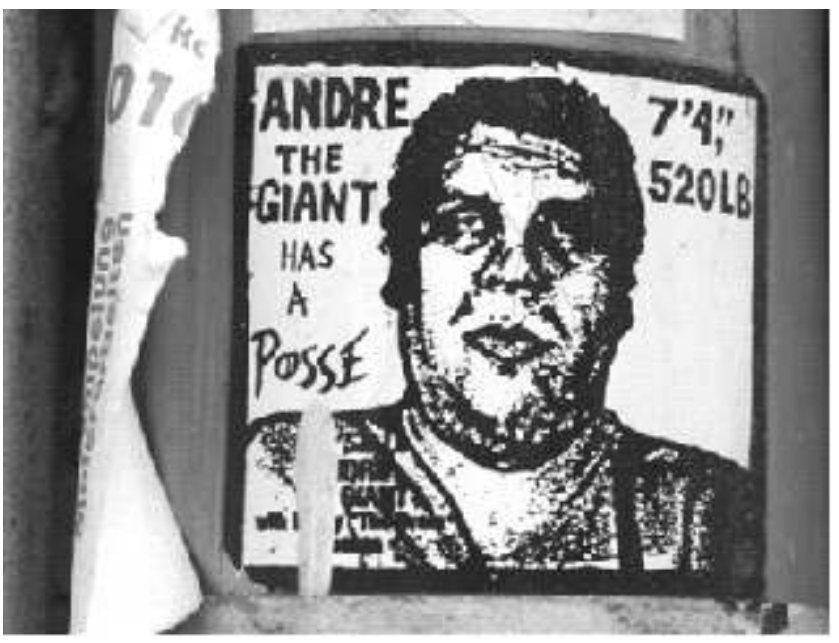

Gambar 3. Poster stensil 'the Giant has a posse'

Sumber: http://andberlin.com/wp-content/uploads/2013/02/shepard-fairey-andre3a9-the-gianthas-a-posse-sticker.jpg

muatan sendiri, Kant memberikan penilaian atas karya tidak lepas dari cara pandang di mana realitas tidaklah terletak pada dunia yang diartikan sebagai kumpulan objek-objek, namun realitas terbentuk dalam benak manusia yang merekonstruksi semua gejala dalam relasi-relasi logis (Wiryomartono, 2001:33).

Obyek yang dipakai pada mulanya adalah dari hasil 'temuan' Shepard di sebuah surat kabar yang memuat iklan dengan gambar seorang pegulat profesional dengan tinggi 7 (tujuh) kaki 4 (empat) inch, dengan berat tubuh 520 pound, Andre 'the Giant'. Struktur wajah dan tatapan mata
Mulai saat itu (1989) Shepard yang menyadari sebuah peluang untuk merubah opini sosial tentang obyek visual, mengajak beberapa temannya memproduksi stiker dan poster lebih banyak dengan berbagai macam variasi, juga $t$ shirt. Keuntungan dari penjualan $t$ - shirt ia pakai untuk membuat stiker, stensil dan poster lebih banyak lagi, begitu dan seterusnya hingga sekarang. Cara penyebaran stiker dan poster yang masif tersebut sebenarnya tidak dilakukan oleh Shepard sendiri. Ia selalu membagi-bagikan stiker dan poster kepada teman-teman, untuk selanjutnya ditempel di seluruh tempat di kota bahkan luar kota 
atau bahkan sampai ke luar negeri. Selain itu ia memberikan instruksi dan cara untuk meng-copy gambarnya dengan gratis, dan memberikan sentuhan atau modifikasi sendiri sesuai dengan apa yang diinginkan. Sudah tidak terhitung lagi berapa jumlah poster yang pernah dibuat dan ditempelkan di berbagai tempat di seluruh dunia.

Pada awalnya fenomena 'Andre The Giant' memunculkan berbagai kontroversi, beragam interpretasi muncul mengenai tujuan adanya poster tersebut, sebenarnya poster dan stiker tersebut adalah iklan, kampanye, atau propaganda. Sebagian besar masyarakat menangkapnya sebagai hal yang biasa dalam dunia publikasi, dimana setiap hal yang ditujukan untuk dilihat dan dinikmati oleh publik selalu mewakili suatu hal tertentu atau bertendensi pada kepentingan seseorang atau lembaga tertentu. Padahal dalam kampanye ini, sesuatu yang dikampanyekan tidak jelas. Ada yang beranggapan bahwa hal itu adalah kampanya politik, grup band, iklan papan skate, atau bahkan sekte aliran baru.

Pendapat dan anggapan beragam yang muncul membuat Shepard berhasil memberikan 'shock therapy' terhadap opini masyarakat yang selama ini berlaku konvensional. Ia melakukannya hanya karena iseng tanpa ada maksud atau pesan tertentu untuk disampaikan secara verbal. Ia tidak dipusingkan oleh muatan apa yang harus dan ingin ia sampaikan lewat manifestasi karyanya tersebut. Justru hal inilah yang menarik, ketika makna selalu ditampilkan dengan cara verbal yang memanjakan sekaligus mengkotakkan pikiran setiap orang; Shepard justru melakukan sebaliknya. Makna dari suatu hal dapat kita bangun dari reaksi kita terhadap hal tersebut. Pandangan masyarakat yang masih berada dalam "konservatifisme visual" itulah yang menjadi tantangan bagi "liberalime visual".
Kemapanan simbolik citra-citra budaya generik menjadi tantangan bagi kreatifitas yang berdasarkan semangat kebebasan menerjemahkan substansi kebudayaan dengan budaya visual diferensial. Dari setiap poster yang tanpa muatan apapun dapat mempunyai berbagai arti tergantung dari tempat dimana kita berada pada saat kita melihatnya. Kuncinya terletak pada "pengembaraan visual”. Sesungguhnya kampanye yang dilakukan oleh Sheppard merupakan bentuk "rekreasi visual" atau eksperimen fenomenologis, yang disebut Heidegger sebagai the process of letting things manifest themselves', suatu bentuk reaksi sosial terhadap atas apa yang terjadi di lingkungan sekitarnya. Sebab tujuan pertama dari fenomenologi adalah untuk membangkitkan rasa ingin tahu atau kepedulian terhadap lingkungan seseorang. Mencoba kritis terhadap persoalan yang ada di sekitarnya.

Gaya poster ala Obey Giant yang diciptakan Shepard Fairy pada pada hakekatnya merupakan hasil dari suatu kratifitas yang muncul melalui proses interaksi sosial antara si desainer (Shepard Fairy) dengan masyarakat yang ada di sekitanya. Terlepas dari apakah ide yang sebenarnya hanyalah main-main yang justru kemudian menjadi gebrakan sebuah gaya visual yang banyak dijadikan acuan bagi orang lain. Di sinilah tampak bahwa karya seni poster merupakan suatu hasil dari proses sosial seperti pandangan dalam perspektif Vera Zoelberg bahwa seni sebagai proses sosial. Dalam konteks poster di Indonesia sebagai contok kasus disini adalah poster Munir, terdapat dua kemungkinan reaksi kontradiktif yang muncul yaitu pro dan kontra dalam menyikapi dan mengapresiasinya.

Pada satu sisi bisa jadi munculnya media tersebut menimbulkan ketidaknyamanan bagi sebagain orang atau kelompok yang merasa 
disudutkan dengan adanya kampanye terhadap isu penyelesaian kasus Munir. Sementara pada pihak lain, dengan adanya poster ini, dapat mengingatkan kembali akan semangat juang sosok Munir yang dapat dapat dimaknai sebagai simbol pergerakan sosial melawan penindasan, dan menjadi teladan bagi orang dengan semangat yang sama. Namun juga sebagai sosok yang dianggap sebagai pengganggu "stabilitas" kekuasaan dari kelompok-kelompok lain.

\section{Pengaruh Masyarakat}

Kembali dalam konteks fenomena Obey Giant, keabsenan/kenihilan makna atau pesan dalam gambar (poster, stensil, dan stiker) menjadi semacam pukulan terhadap kultur pasif konsumtif masyarakat yang lebin banyak mengharapkan sesuatu yang verbal dari setiap hal. Kita sebenarnya bebas untuk melakukan apa saja terhadapnya, pro atau kontra bahkan cemooh dan hinaan bebas kita lakukan selama apresiasi tersebut bisa memicu kepedulian terhadap apa yang terjadi di sekeliling kita dan muncul dialogdialog aktif positif tentangnya. Bagi yang sudah pernah melihat poster atau stikernya, 'obey' bisa berarti 'obey' (patuh), juga bisa berarti 'disobey' (tidak patuh). Kedua hal yang saling bertentangan ini biasanya mewakili dua golongan sosial yang saling beroposisi dalam berbagai hal bahkan sangat mungkin saling membenci dan menjatuhkan.

Bagi mereka yang mengartikannya sebagai 'obey', biasanya tahu tentang latar belakang sejarah gambar, ikon atau warna yang ditampilkan pada gambar, dan rata-rata mereka membencinya karena mereka menganggap sebagai media propaganda komunis, neo NAZI, sekte aliran baru, atau hal-hal lainnya yang negatif dan radikal. Sebaliknya, mereka yang menyukai kampanye tersebut, disebabkan oleh: pertama, karena mereka tahu kalau golongan yang tidak mereka suka (golongan atas) membenci kampanye tersebut, kedua karena pengetahuan mereka yang kurang tentang sejarah sumber inspirasi Shepard, sehingga mereka mengira kampanye tersebut adalah kampanye tentang grup band punk, merek papan skate, atau bentuk graffiti baru, ketiga karena masifnya gerakan ini, sehingga membuat mereka tertarik untuk ikut menjadi bagian di dalamnya, sekalipun mereka tidak tahu tentang apa sebenarnya gerakan ini selain ketertarikan mereka pada desain grafis poster, kaos, dan stiker yang sering juga menampilkan gambar tokohtokoh idola, seperti Andy Warhol, Martin Luther King, Che Guevara, Emilianio Zapata, Angela Davis, Jam Master Jay, Public Enemy, Henry Rollins, Sid Vicious, Joseph Stalin, Jesse Jackson, dan banyak lagi yang merupakan tokoh publik simbol gerakan sosial.

Gambar-gambar yang biasa dipakai Shepard meliputi elemen propaganda sejarah, ikon pop culture, parodi kekuasaan, dan 'black power' sebagai simbol untuk mendekonstruksi kekuatan visual yang dipadukan dengan kata-kata provokatif, yang secara emosional berpotensi untuk mendoktrinasi, menghipnotis atau bahkan menipu. Reaksi yang bermunculan bermacammacam, baik yang pro maupun kontra. Mulai dari merusak atau merobek, menambahi dengan katakata makian, sampai melaporkan pada pihak yang berwajib dilakukan oleh yang merasa terganggu dengan keberadaan poster-poster dan stiker itu. Golongan reaksioner seperti ini selalu bereaksi tanpa pikir panjang terlebih dulu. Satu point lagi yang ingin disampaikan Shepard yaitu kebiasaan untuk berpikir terlebih dulu sebelum bereaksi terhadap sesuatu. Akibat ulah para pelapor yang paranoid karena pola pikirnya sendiri tersebut. 
Shepard sempat berurusan dengan aparat keamanan dan menginap dalam penjara beberapa kali.

Reaksi pro dan kontra ini sangat tinggi intensitasnya, mengingat media yang dipakai sebagai perantara antara Shepard dan publik adalah 'jalanan'itu sendiri. Jalanan dan ruang terbuka publik menjadi arena propaganda visual. Siapa saja dan dari golongan apa saja bisa langsung mengapresiasi seni grafis propaganda Shepard, tanpa harus membayar atau mengunjungi galeri tertentu. Sebab arena yang menampung lautan gambar, simbol, ikon, dan pesan adalah 'jalanan'. Shepard lebih memilih jalanan sebagai 'galeri' untuk memamerkan karyanya, karena rumah seni atau galeri seni hanyalah sebuah kolam atau danau semata, bukan lautan bagi artis yang banyak terinspirasi oleh Andy Warhol, Dave Arron, Phil Frost, Arron Rose, Twist, Mike Mills, Adam Wallcavage, Misha Hollenbach, dan Ken Sigafoos ini. Disamping itu dengan peran internet, galeri 'jalanan' Shepard sekarang telah mendunia hingga barangkali ia sendiri tak tahu pasti seberapa banyak karyanya diakses dan disebarluaskan oleh publik. Hingga muncul banyak Shepard-Shepard baru, dan gerakan menjadi semakin besar dan meluas.

Kehidupan seni dan masyarakat adalah dua kelompok yang mempunyai kepentingan yang berbeda, walaupun diantara keduanya terdapat hubungan yang tidak dapat dipisahkan. Dalam masyarakat, ada beberapa kelompok kelas sosial yang terkait dengan sosio-profesional seperti yang dikemukakan Bourdieu yaitu pertama kelas borjuasi lama seperti bos-bos perusahaan besar dan industri, disamping borjuasi baru yang terdiri dari para eksekutif sektor swasta yang berasal dari sekolah prestisius (modal ekonomi), para dosen, dan kaum intelektual (modal budaya). Kedua kelas borjuasi kecil yang terdiri dari kelas menengah dalam kelompok sosial seperti karyawan, wiraswasta, atau pengusaha. Disamping itu ada kelompok borjuis kecil baru yang terdiri dari para seniman, intelektual dan konsultan, termasuk di dalamnya animator televisi. Ketiga kelompok kelas populer yang terdiri dari para buruh pabrik dan buruh tani.

Dari kelompok kelas sosial masyarakat seperti yang dikemukakan di atas, seniman ditempatkan pada kelas borjuasi baru kecil, dan berarti mereka dihadapkan pada keinginan menaiki tangga atau kelas sosial yang lebih tinggi dan ditandai dengan nilai ekonomi yang lebih kuat. Karena kaum borjuasi menurut Bourdieu, yaitu keinginan untuk menaikkan tangga sosial, sudah barang tentu tidak semudah yang diperkirakan untuk menaiki tangga atau kelas sosial yang diharapkan seniman. Hal yang tampak paradok memang bagi seniman, namun semuanya itu sangat terpulang kembali pada pribadi mereka dalam menjalani proses kreatif untuk menghasilkan karyanya.

Kini wajah Andre the Giant tidak saja menjadi poster dan stiker tanpa makna, tetapi sudah menjadi ikon propagandis yang fleksible untuk beberapa subkultur. Dengan tambahan embel-embel 'OBEY' yang diadopsi dari federasi Gulat Bebas WWF, kampanye Shepard secara psikologis mempunyai dua arah yang saling berlawanan. Bagi seorang yang konservatif, sebuah gambar Stalin atau tokoh lain dalam dunia politik disertai kata 'obey' merupakan kampanye politik yang kental, ditambah dengan pemilihan warna merah hitam dan putih yang sangat identik 
dengan komunis. Padahal pemilihan warna hanya dikarenakan oleh masalah teknis dan estetis visual belaka. Kampanye yang lebih bersifat parodi ini
2009 di Institut of Contemporary Art, Boston.

Dalam pameran tersebut di tampilkan berbagai karya seni dengan berbagi eksplorasi media,

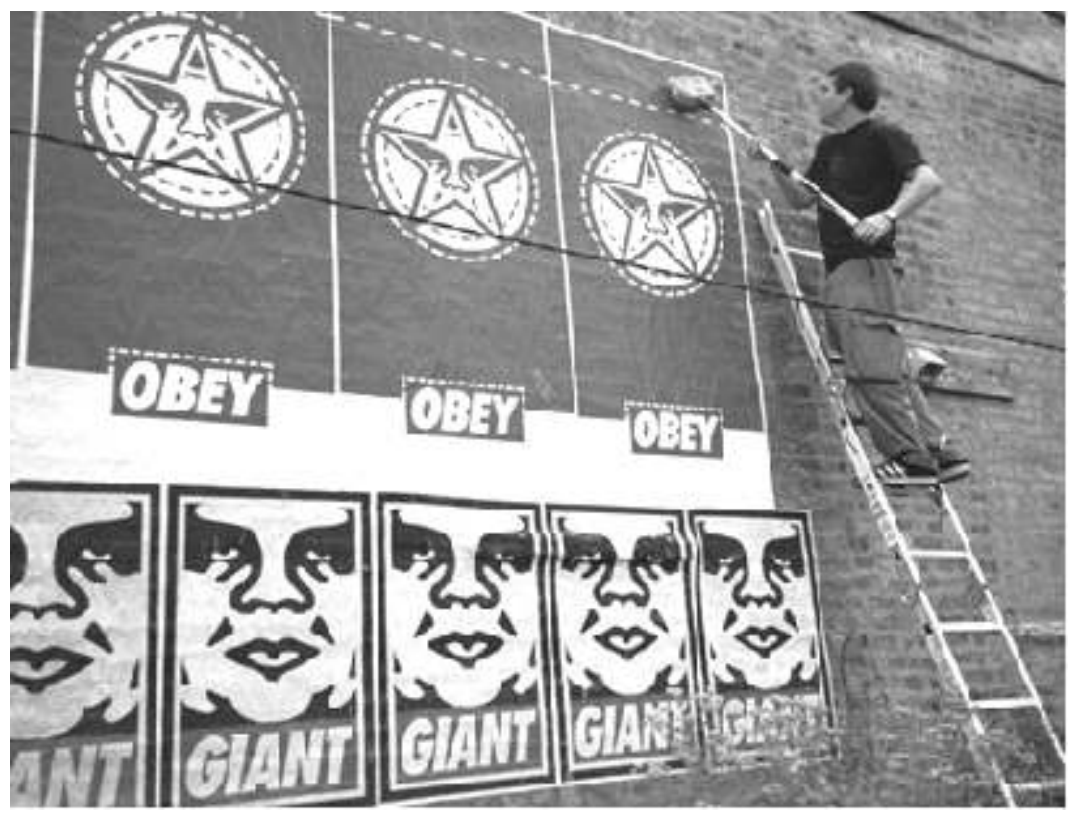

Gambar 4. Poster Obey the Giant

Sumber : http://farm1.staticflickr.com/222/448189901_1e212f8f79_o.jpg

merefleksikan kebalikan dari apa yang disampaikan (obey), Shepard menyebutnya sebagai 'Reverse Psychology'.

\section{Peran Institusi Sosial}

Sebagai sebuah gerakan seni avant garde, yang umumnya mengalami keterasingan dan bahkan seringkali dicemooh dan dipinggirkan. Proses yang panjang diperlukan bagi Shepard Fairy dalam mengkonstruksikan seni yang dibuatnya menjadi entitas karya seni yang akhirnya memperoleh tempat yang baik dalam lingkungan dunia kesenian. Saat ini banyak karyanya yang dikoleksi berbagai galery dan museum. Secara ekonomi membuka peluang baru dengan adanya industri fahsion yang berorientasi pada gaya Obey Giant. Shepar Fairy telah membangun brand Obey sebagai kendaraan bisnisnya yang telah tersebar ke beberapa negara.

Pencapaian tersebut diawali saat pameran seni bertajuk Supply and Demand, pada tahun berupa, screen printing, stencil, stiker, kolase, seni cukil kayu, logam dan media kanvas. Sebagai salah satu peserta, Shepard Fairy menampilkan karya seni ruang publik yang ditempelkan di beberapa tempel sekitar lokasi pameran. Gagasan di dasari atas motivasinya bahwa pesan sesungguhnya dibalik semua karya yang di tampilkannya adalah "mempertanyakan segala sesuatu".

Satu hal yang cukup fenomenal yang akhirnya semakin membuatnya di kenal di seluruh dunia adalah pada saat pemilu presiden tahun 2008 ketika ia membuat konsep poster kampanye Barack Obama dengan slogan 'Hope'. Karya yang dibuatnya murni atas dasar ketertarikan pada sosok Obama yang di anggapnya dapat membawa perubahan di Amerika. Poster yang dibuatnya menjadi satu bentuk ungkapan kreatif dalam mengungkapkan satu gagasan atau dalam kontek poster Obama merupakan satu bentuk dukungan dan simpatinya terhadap sosok Obama. 


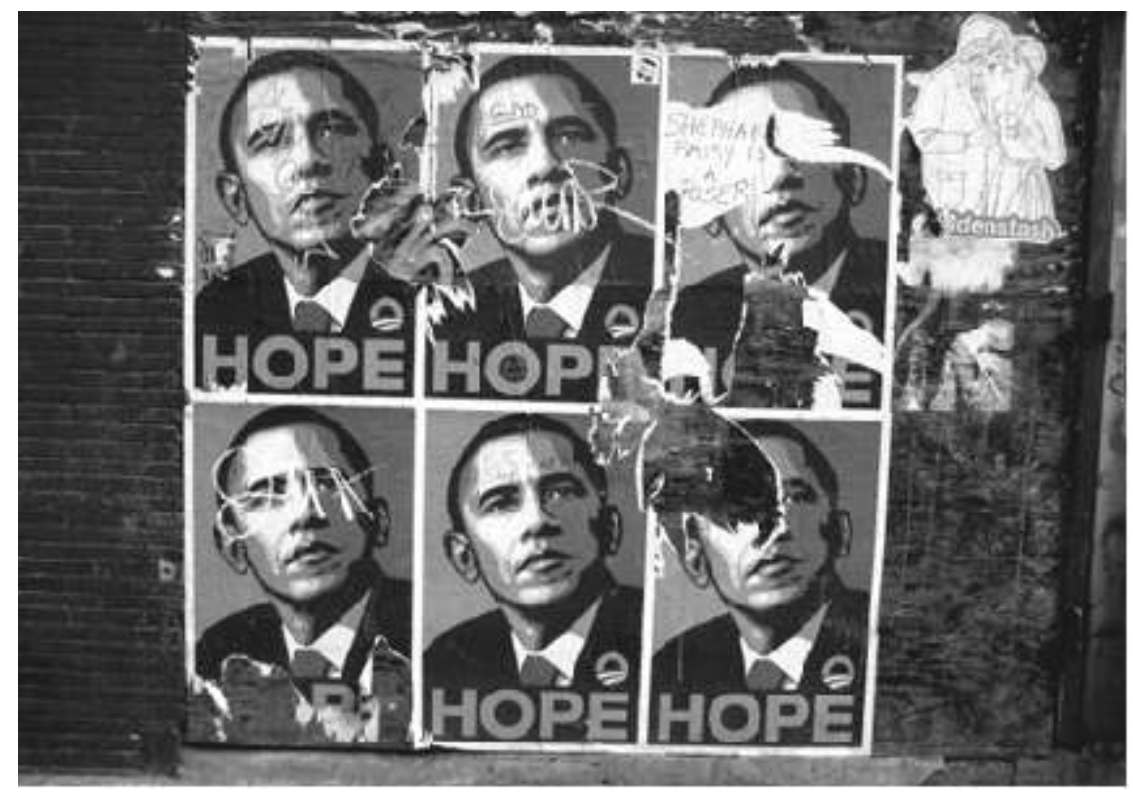

Gambar 5. Poster kampanye Presiden Barack Obama Sumber: http://farm4.staticflickr.com/3448/3366453451_c3605565aa_o.jpg

Proses kreatif dimulai dari dalam diri manusia berupa pikiran, perasaan atau imajinasi kreatif manusia kemudian dituangkan menggunakan media dan teknik tertentu, sehingga melahirkan karya-karya kreatif. Utami Munandar (dalam Zahri Jas, 1995: 2) menyatakan bahwa secara luas kreativitas bisa berarti sebagai potensi kreatif, proses kreatif dan produk kreatif. Proses kreativitas melalui kegiatan seni adalah jalan sebaik-baiknya yang dapat dilakukan sebab melakukan kegiatan seni berarti terjadi suatu proses kreatif.

Dampak dari adanya seri poster tersebut ternyata sangat mempengaruhi konstelasi pertarungan politik yang akhirnya dimenangkan oleh Obama. Bahkan akibat peran poster tersebut, ia mendapat surat langsung dari Obama atas partisipasinya dalam mendukung Barack Obama. Dan sebagai bentuk penghargaan atas dedikasi pula, maka pada tahun 2009, poster HOPE dijadikan sebagai koleksi oleh US National Portrait Gallery. Berbagai karyanya juga telah dikoleksi antara di Smithsonian, Los Angeles County Museum of Art, Museum of Modern Art di
New York, Museum of Contemporary Art San Diego, Virginia Museum of Fine Arts di Richmond, dan Victoria and Albert Museum London.

Dari uraian tersebut tampak peran institusi seni dan politik memberi andil terhadap kedudukan seorang Shepard Fairy sebgai salah satu seniman kontemporer yang disegani. Dalam konteks sosiologi seni, yang dialami oleh Shepard Fairy sesuai dengan perspekstif Vera Zoelberg bahwa seniman dalam berkarya terlahir karena adanya bakat dan konsistensi dalam gagasan seninya, sementara dalam konteks kekeberadaan dan kedudukannya tidak dapat lepas dari peran struktur sosial masyarakat penyangganya, baik institusi dan lembaga seni, institusi politik, media massa dan masyarakat.

\section{Kesimpulan}

Melalui telaah pandangan yang dikemukakan tersebut menurut Vera L. Zolberg, dalam bukunya Constructing a Sociology of the Art diungkapkan bahwa; objek seni sebagai proses sosial, melalui pengertian ini karya seni dipahami 
atas dasar proses penciptaannya sehingga suatu karya yang didefinisikan sebagai seni, selanjutnya seni sendiri menjadi sebuah objek yang harus direkonstruksi untuk menunjukkan aspek struktur sosial dan proses menggunakan sumber-sumber indikator apapun yag tersedia.

Eksistensi poster gaya Obey memancing setiap orang untuk bereaksi, berkontemplasi, dan mencari makna dari setiap poster atau stiker tersebut. Di lain pihak keabsenan makna dari setiap poster dan stiker tersebut justru malah merefleksikan pribadi dan sensitifitas individu yang bersangkutan, terhadap lingkungan sekelilingnya. Terserah kita untuk memaknai dan menyikapinya. Cobalah untuk terus menginterpretasi manifestasi tersebut, karena makna yang kita dapatkan adalah pencerminan dari siapa dan bagaimana anda sebenarnya. Di samping itu, kita hanyalah sebuah 'tabula rasa' dan kadang kita butuh sebuah reflektor untuk sekedar tahu kira-kira siapa kita sebenarnya.

Karya seni yang lahir dari gagasan individu yang kemudian didistribusikan secara masif ternyata mampu mempengaruhi persepsi setiap elemen dalam masyarakat untuk memberikan apresiasi yang posistif terhadap hasil karya tersebut. Dalam hal ini upaya yang dilakukan Shepard Fairy menjadikan salah satu seniman dengan orietasi sosialisnya tidak menjadikan halangan untuk dihargai oleh setiap instrumen sosial bahkan yang barangkali berseberangan secara ideologi sosial dengan dirinya.

Pada pandangan ini suatu karya seni dianggap sebagai produk usaha bersama antara komponen-komponen yang membentuk seniman dan karyanya. Pandangan tersebut juga memiliki hubungan dengan pendekatan Howard S. Becker, dalam bukunya Art Worlds, bahwa seni sebagai konstruksi sosial yang dipahami secara baik dengan melibatkan beberapa aktor ternasuk beberapa yang kekuasaan sosialnya memungkinkan mereka untuk menekankan nilai pada objek yang dalam ditunjukkan adanya peran gallery, museum, kalangan politik, maupun gerakan sosial yang secara aktif menerapkan dalam berbagai tujuan kepentingan.

Sekali lagi yang perlu di garis bawahi adalah bahwa gerakan kampanye ini lebih bermaksud untuk menstimulasi rasa ingin tahu dan membuat setiap orang bertanya-tanya, sehingga mencoba menghubungkan kampanye tersebut dengan keadaan di sekitar mereka. Hal ini relatif sulit dilakukan apabila si pencipta karya tidak memiliki kepekaan sosial, pemahaman akan lingkungan sosialnya dan intuisi logis dalam melihat realitas dalam kehidupan yang ada disekitarnya.

Jerih payah berkarya poster yang dilakukan Shepard Fairy meskipun berangkat dari suatu hal yang tadinya tidak bermakna, ternyata di kemudian hari memberikan pengaruh besar bagi kehidupan dirinya, masyarakat dan elemen institusi kebudayaan dan pendidikan, yang menjadikan karya-karyanya mendapat apresiasi yang sangat baik dan menginspirasi pada desainerdesainer lainnya. 


\section{Daftar Pustaka}

Bernstein, David. 1997, Advertising Outdoors: Watch This Space! London: Phaidon Press.

Becker, Howard S. 1982, .Art World. Barkeley: University of California Press

Bastomi, Suwaji. 1990. Wawasan Seni Semarang. IKIP Semarang Press

Gie, The Liang. 1976, Garis-garis Besar Estetik (Filsafat Keindahan). Fakultas Filsafat Universitas Gadjah Mada.

Myers, G. 1999. Ad Worlds: Brands, Media Audiences. London: Edward

Wiryomartono, Bagoes P. 2001, Pijar-Pijar Penyingkap Rasa: Sebuah Wacana Seni dan Keindahan dari Plato sampai Derrida. Jakarta: Gramedia Pustaka Utama.

Zahri, Jas. 1995, Pengembangan Budaya Kreatif Dan Nilai-nilai Estetik Dalam Pendidikan Seni. Seminar Nasional Konsep dan Implementasi Pendidikan Seni

Zolberg, Vera L. 1990, Constructing a Sociology of the Arts. Canbridge : Canbridge University Press.

http://antitankproject.files.wordpress.com/2008/0 9/weekend-work4.jpg, diunduh pada tanggal 30 Oktober 2013, pukul 19.25 WIB

http://www.theblaze.com/stories/2012/02/24/artis t-behind-obama-hope-poster-pleadsguilty-to-criminal-contempt-in-nyc/, diunduh pada tanggal 30 Oktober 2013, pukul 19.43 WIB

h t t p : / / a n d b e r 1 i n . c o m / w p content/uploads/2013/02/shepard-faireyandrc3a9-the-giant-has-a-possesticker.jpg, diunduh tanggal 30 Oktober 2013, pukul 20.52 WIB

http://farm4.staticflickr.com/3448/3366453451_c 3605565aa_o.jpg, diunduh pada tanggal 30 Oktober 2013, pukul 20.34 WIB

http://farm1.staticflickr.com/222/448189901_1e2 12f8f79_o.jpg, diunduh pada tanggal 30 Oktober 2013, pukul 21.14 WIB 